\title{
Demencia prevenció: A korai diagnózistól a személyre szabott intervencióig
}

\author{
Manga Annamária ${ }^{1,2,}$, Havadi-Nagy Menta ${ }^{1}$, Székely Orsolya ${ }^{1}$, Vidnyánszky Zoltán ${ }^{1, *}$ \\ ${ }^{1}$ Természettudományi Kutatóközpont, Agyi Képalkotó Központ, Budapest, Magyarország \\ ${ }^{2}$ Budapesti Mûszaki és Gazdaságtudományi Egyetem, Kognitív Tudományi Tanszék, Budapest, Magyarország
}

Beérkezett: 2021. május 6.; Elfogadva: 2021. június 9.

\begin{abstract}
Összefoglalás
Az elmúlt évtizedekben a várható élettartam emelkedésével drámai mértékben nőtt a demencia előfordulásának gyakorisága, melynek hátterében leggyakrabban az Alzheimer-kór áll. A rendkívül ígéretes, biomarkereken, agyi képalkotáson és mesterséges intelligencián alapuló megközelítéseknek köszönhetően egyre szélesebb körú információink vannak a betegség kialakulásáról és lefolyásáról, új kapukat nyitva ezzel a demencia korai diagnózisa és a személyre szabott terápia felé. Míg az új kutatási irányzatok előnye vitathatatlan, a nagy mennyiségű kutatási adat kezelése, illetve a betegség korai szakaszban történő azonosítása több biztonsági kérdést felvet. A korai diagnózis mellett egyre nagyobb hangsúly helyeződik az intervencióra, a demenciára hajlamosító tényezőkbe történő beavatkozás által.
\end{abstract}

Kulcsszavak: Alzheimer-kór, demencia, MRI, biomarker

\author{
Dementia Prevention: From Early Diagnosis to Personalised Intervention \\ Annamária Manga ${ }^{1,2, *}$, Menta Havadi-Nagy ${ }^{1}$, Orsolya Székely ${ }^{1}$,Zoltán Vidnyánszkyl, \\ ${ }^{1}$ Research Centre for Natural Sciences, Brain Imaging Centre, Budapest, Hungary \\ ${ }^{2}$ Budapest University of Technology and Economics, Department of Cognitive Science, Budapest, Hungary
}

\begin{abstract}
Summary
As a consequence of increasing life expectancy, the number of those living with dementia is rising. While Alzheimer's disease $(\mathrm{AD})$ constitutes the most common cause of dementia, the origin of $\mathrm{AD}$ is unknown. Furthermore, in the absence of effective treatment, therapy focuses on the cognitive and behavioural symptoms of the disease, and the wellbeing of the patient. $\mathrm{AD}$ is characterised by a pronounced impairment experienced in one or more cognitive domains, and the criterion of the diagnosis is the presence of aggregated proteins in the brain leading to neuron death, and eventually to the loss of cognitive abilities.

As a result of the latest technological advances, several biological markers (biomarkers) of AD pathology were identified. The biomarkers can be obtained using positron emission tomography or measured from cerebrospinal fluid, and lately from blood serum and plasma as well. Magnetic resonance imaging provides an important measure of brain atrophy, a biomarker of neurodegeneration and neuronal injury. The structure of the brain shows significant alterations as a function of neuronal loss, with cortical thinning and tissue density changes, mainly starting from the medial temporal lobes (also including the hippocampus playing a prominent role in memory functions), and extending to the temporoparietal regions, with observed changes in the activity of the different functional brain networks as well.

A major challenge in defeating $\mathrm{AD}$ is that in most cases, the disease is recognised subsequent to the appearance of the decline in cognitive abilities, hampering everyday life. Previous studies identified a preclinical stage of AD, where the biomarkers indicative of the disease are present in the absence of detectable cognitive symptoms. This early, preclinical stage - with the use of artificial intelligence-based techniques - has been suggested to be a promising window for the early detection of the disease, and also for the prediction of individual disease trajectories, allowing for the thorough planning of patient management. While the benefit of the early diagnosis is unequivocal, it raises a number of important ethical and safety issues.
\end{abstract}


Besides the tremendous effort of developing effective medical treatments, the importance of intervention stands in the centre of scientific interest. The proposed prevention and intervention methods target the potentially modifiable risk factors of dementia, encouraging engagement in stimulating everyday activities and healthy lifestyle, to preserve longevity.

Keywords: Alzheimer's disease, dementia, MRI, biomarker

\section{A demencia és típusai}

Demencia alatt az egy vagy több kognitív területen - így a tanulásban, memóriában, nyelvi képességekben, térivizuális információfeldolgozásban, figyelemben, végrehajtó folyamatokban - jelentkező funkcióvesztés értendő, mely következtében a mindennapi teendők hatékony elvégzése is súlyos csorbát szenved (Arvanitakis-ShahBennett 2019). A kognitív funkciók károsodása időskorban jelentkezik, ezáltal az egyén életkorát kijelölve mint az egyik legfontosabb - és egyben elkerülhetetlen - kockázati tényezőt a demencia kialakulásában (ArvanitakisShab-Bennett 2019; Grande-Qiu-Fratiglioni 2020). Ennek fényében a várható élettartam növekedése magával hozta a demenciával élők számának emelkedését, ezzel felhívva a figyelmet a világszintű egészségügyi, gazdasági és egész társadalmat érintő hatására (Fratiglioni-Marseglia-Dekbtyar 2020).

A demencia számos betegség következtében kialakulhat, melyek közül az Alzheimer-kór (Alzheimer's disease) a leggyakoribb és leginkább kutatott kiváltó ok (Hampel et al. 2018; Milà-Alomà-Suárez-Calvet-Molinuevo 2019; Patterson 2018). Egyre gyakoribb a Lewy-testes demencia, a frontotemporális demencia és a vaszkuláris demencia is, valamint a kognitív hanyatlás hátterében állhat még - a teljesség igénye nélkül felsorolva - Parkinsonkór, Huntington-kór, progresszív szupranukleáris bénulás, kortikobazális degeneráció, multiszisztémás atrófia, Creutzfeldt-Jakob-betegség, de akár traumás agysérülés és sclerosis multiplex is (Arvanitakis-Shab-Bennett 2019). A szindrómát tovább árnyalja, hogy az egyes betegségek nem csupán önállóan eredményeznek funkciócsökkenést, hanem gyakori esetben több patológia együttesen fejti ki negatív hatását, így például Alzheimerkór cerebrovaszkuláris betegséggel társulva (Arvanitakis-Shah-Bennett 2019; Ashton et al. 2020; Livingston et al. 2020), valamint hogy a demenciát sok esetben neuropszichiátriai és viselkedéses zavarok is kísérik, mint például apátia, depresszió (Arvanitakis-Shab-Bennett 2019). A különböző potenciális kiváltó betegségek klinikai tünetei és neuropatológiai hátterei is nagy átfedést mutatnak egymással, egyúttal pedig magas a heterogenitásuk egyének között, így a demencia okának differenciáldiagnózisa a mai napig komoly kihívást jelent (Ashton et al. 2020; Chételat et al. 2020; Hampel et al. 2018).

Az elmúlt évtizedek fokozott kutatási érdeklődésének köszönhetően számos tényező feltárásra került a demencia neurodegeneratív formáit kísérő biológiai változásokról (Grande-Qiu-Fratiglioni 2020). Azonban annak el- lenére, hogy a demencia kapcsán az Alzheimer-kór a leginkább tanulmányozott betegség (Patterson 2018), a betegség sporadikus - az Alzheimer-kór elszórtan, családi halmozódást nem mutató, leggyakoribb - formájának etiológiája a mai napig ismeretlen (Arnsten et al. 2021), továbbá nincs olyan gyógyszeres kezelés, amely a betegséget megszüntetné vagy a lefolyását hatékonyan módosítaná (Goetzl 2020; Grande-Qiu-Fratiglioni 2020). Ebből kifolyólag az Alzheimer-kór tanulmányozása kiemelten fontos kutatási terület, melynek legújabb eredményei állnak a jelen összefoglaló fókuszában.

\section{Kognitív hanyatlás Alzheimer-kórban}

Az Alzheimer-kór egy progresszív, neurodegeneratív rendellenesség, mely egyes becslések szerint a demencia esetek 60-80 százalékáért felelős (Al Mamun et al. 2020; Garre-Olmo 2018; Rabman et al. 2020; Uddin et al. 2018, 2019). Az Alzheimer-kór egyik leggyakoribb jele a mindennapi életet megzavaró memóriavesztés, különös tekintettel a nemrégiben tanult információk elfelejtésére (Grober et al. 2008). A változás abban is megfigyelhető, hogy az illető hogyan képes kidolgozni és követni egy tervet, vagy számokkal dolgozni (Marshall et al. 2011), így probléma lehet akár egy ismert recept vagy a havi számlák nyomon követése. Problémák jelenhetnek meg a vizuális információk és a térbeli viszonyok megértésében (Morris-Kopelman 1986). Néhány beteg esetében előfordulnak látási, olvasási nehézségek, távolság, szín vagy kontraszt megítélését befolyásoló problémák, amelyek zavart okozhatnak többek között vezetés közben (Fitten et al. 1995; Nissen et al. 1985; Pache 2003; TrickSilverman 1991; Tzekov-Mullan 2014). Ugyanígy beszéd közben, írásban vagy egy beszélgetés követésében is jelentkezhet nehézség (Appell-Kertesz-Fisman 1982; Murdoch et al. 1987). Az Alzheimer-kórban szenvedőknek megváltozhat az ítélóképessége, ami megalapozatlan döntésekhez vezethet például a pénz kezelésében (Wadley-Harrell-Marson 2003). A kogníció romlásán kívül a betegek hangulata és személyiségjegyei is megváltozhatnak, és zavarodottá, gyanakvóvá, depresszióssá vagy szorongóvá válhatnak (Balsis-Carpenter-Storandt 2005). A magatartási és pszichológiai tünetek alkotják a demenciák viselkedéses tünetcsoportját, melyek közül az Alzheimer-kórra leginkább az érdeklődés elvesztése, a szorongás, a depresszió, a fokozott ingerlékenység, és a nyugtalan, helyzethez nem illő viselkedés jellemző (Kales-Gitlin-Lyketsos 2015; McKeith-Cummings 2005). A kognitív és viselkedéses tünetek általában tükrözik az 
idegsejtek károsodásának mértékét, így fokozatosan alakulhatnak ki, és az évek során jellemzően egyre súlyosabbá válnak (Alzheimer's Association 2019). Az Alzheimerféle demencia enyhe stádiumában a legtöbb ember képes számos területen önállóan múködni, de egyes tevékenységeknél segítségre van szüksége. A mérsékelt stádiumban - amely gyakran a leghosszabb szakasz - az egyéneknek nehézségei lehetnek a kommunikációban és a rutinfeladatok elvégzése során, beleértve olyan mindennapi tevékenységeket is, mint a fürdés, öltözködés (Giebel-Sutcliffe-Challis 2015). A betegség súlyos stádiumában a betegek éjjel-nappali ellátást igényelnek és ágyhoz kötötté válnak (Aggarwal et al. 2006; Kluger et al. 1997).

Klinikai és patológiai tünetek alapján az Alzheimer-kór két nagyobb csoportja, a típusos és az atípusos forma különböztethető meg. A típusos formára kimondottan az epizodikus memória korai zavara jellemző. Egyes becslések szerint az Alzheimer-kór eseteinek 6-14 százaléka eltér a típusos amnesztikus formától, és a betegség lefolyása során egyéb kognitív területek károsodása jelenik meg markánsan. Az atípusos formán belül eddigi tudásunk szerint négy variáns különíthető el: (1) a poszterior variáns, melynél a vizuális észlelés (például betúk, szavak vagy arcok felismerése) vagy a téri-vizuális funkciók (térbeli látás, orientáció és látás alapján vezérelt mozgás) sérülnek, (2) a logopéniás variáns, melynek jellemzője a szavak elfelejtése, mondatok megismétlése, (3) a frontális variáns, melynek fó tünete a viselkedés korai megváltozása, a végrehajtó funkciók romlása és az apátia, és (4) a Down-szindróma variáns, mely a Down-szindrómával élők között fordulhat elő, és a viselkedésben bekövetkező változásokkal, valamint a végrehajtó funkciók romlásával jár együtt (Dubois et al. 2014).

\section{Diagnózis és biomarkerek}

A demencia megállapítása a legtöbb esetben akkor történik meg, amikor a beteg vagy hozzátartozója a már megtapasztalt kognitív funkciócsökkenés kapcsán jelentkezik orvosánál. A 2013 óta érvényben lévő Mentális Betegségek Diagnosztikai és Statisztikai Kézikönyve (Diagnostic and Statistical Manual of Mental Disorders, DSM-5) szerint a demencia - újabb nevén major neurokognitív zavar - diagnózisának feltétele a kognitív funkciók legalább egy területének olyan mértékủ károsodása a beteg korábbi képességeihez viszonyítva, mely a beteg munkában, illetve hétköznapi életben való boldogulását jelentősen hátráltatja (Arvanitakis-Shab-Bennett 2019). Az Alzheimer-kór azonosításában a 2000-es évek közepéig a demencia diagnosztikai kritériumainak teljesülése, és ezzel együtt az egyéb, demenciát okozó betegségek kizárása volt az irányadó. Mivel az Alzheimer-kór megállapításának feltétele a betegségre jellemző, az agyban kórosan felgyülemlő fehérjék (béta-amiloid plakkok és tau neurofibrilláris kötegek) jelenléte (Milà-Alomà-SuárezCalvet-Molinuevo 2019), a definitív orvosi diagnózist a halált követően, neuropatológiai vizsgálattal lehet felállí- tani (Hampel et al. 2018). A technológia fejlődésével azonban időközben elérhetővé váltak olyan eszközök, melyek segítségével az Alzheimer-kórra jellemző degeneratív változások in-vivo, az élő szervezeten belül is detektálhatók (Hampel et al. 2018). Ennek következtében napjainkban a betegség diagnózisa egyre inkább a biológiai jegyek alapján történő meghatározás irányába halad, melyben kiemelt szerepet kaptak a biomarkerek (Chételat et al. 2020). Biomarkernek nevezik azokat a biológiai jellemzőket, egységeket, melyek számszerúsíthetők, és ezáltal képesek információt közvetíteni arról, hogy a különböző betegségek, állapotok milyen hatást gyakoroltak a szervezetre (Lamb et al. 2021). A 2018-ban aktualizált $A T(N)$ nevet viselő kutatási megközelítés nagyban hozzájárult az Alzheimer-kór strukturált jellemzéséhez azáltal, hogy a betegségben korábban azonosított biomarkereket három csoportba osztotta (Jack et al. 2018; Shen et al. 2020). Az AT(N) elnevezés $A$ betűje a béta-amiloid peptid jelenlétére utal, mely felhalmozódva szenilis plakkokat alkot az agyban, az idegsejteken kívüli térben (Ebenau et al. 2020; Milà-Alomà-Suárez-Calvet-Molinuevo 2019). A béta-amiloid kóros lerakódása elsőként az agykéregben jelentkezik, ezt követi az entorhinális kéreg és a hippokampusz, a bazális ganglionok és egyes agytörzsi magok, végezetül további agytörzsi magok és a kisagy válnak érintetté (Thal et al. 2002). Az AT(N) T betűje a tau fehérjére utal, mely kórosan foszforilálva halmozódik fel az idegsejten belül, a sejttestben neurofibrilláris kötegeket (neurofibrillary tangles), az idegsejtek dendritjében pedig neuropil thread-eket alkotva, a sejt halálához vezetve (Arnsten et al. 2021; Braak et al. 2011). A tau patológia agyon belüli terjedésének eddig uralkodó nézete szerint a tau felhalmozódása elsőként az agykéreggel gazdag kapcsolatokat alkotó magokban (így a locus coeruleusban) jelenik meg, majd ezt követően az entorhinális régióban jelentkezve terjed tovább a hippokampuszra, a prefrontális és parietális asszociációs kérgi területekre, végezetül pedig a szenzoros és szomatomotoros agykéregre (Arnsten et al. 2021; Braak et al. 2011). Egy újabb, egyedülállóan nagy mintán végzett kutatás szerint viszont a tau patológia nem írható le egy, az Alzheimer-kórra általánosan jellemző tér-idői mintázattal, és a terjedésben megfigyelhető variabilitás alapján a betegség négy altípusa - a limbikus, a parietális, a poszterior és a laterális temporális variáns - különíthető el (Vogel et al. 2021). A biomarkerek AT(N) szerinti $N$ csoportja a nem Alzheimer-specifikus neurodegenerációt, az idegsejteket és gliasejteket érintő sérüléseket jellemzi, melyek egyéb betegségek során is megjelenhetnek. Erre utal a zárójel az elnevezésben, azonban mivel a degeneráció biomarkereinek jelenléte kombinációban az amiloid és tau biomarkerekkel fontos információt tartalmaz, mindenképp indokolt figyelembe venni és bent tartani az AT(N) klasszifikációs rendszerben (Jack et al. 2018).

A béta-amiloid jelenleg legszélesebb körben elfogadott biomarkerei a béta-amiloidhoz kötődő radiofarmakont alkalmazó pozitronemissziós tomográfia (PET) so- 


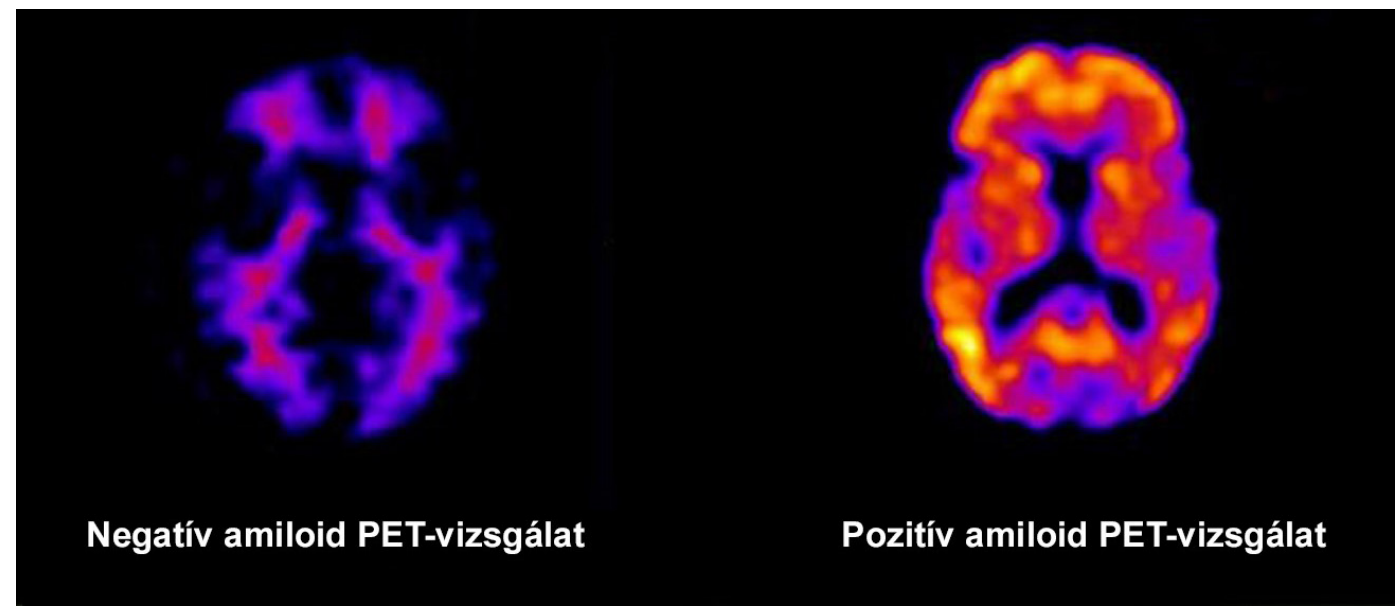

1. ábra

${ }^{11}$ C-izotóppal jelzett Pittsburgh compound B $\left(\left[{ }^{11} \mathrm{C}\right]-\mathrm{PiB}\right)$ vegyülettel végzett PET/CT-felvétel kóros mértékủ fehérjelerakódást (jobb oldal, pozitív amiloid PET-vizsgálat) és annak hiányát (bal oldal, negatív amiloid PET-vizsgálat) mutatva. A $\left[{ }^{11} \mathrm{C}\right]$-PiB vegyület az agyban lerakódott amiloidhoz kötődik, így alkalmas az Alzheimer-kórra jellemző béta-amiloid aggregátumok megjelenítésére. A képen az amiloidhoz kötődött jelzőanyag eloszlása látható, a világosabb (sárgább) árnyalatok nagyobb mennyiségú kötött jelzőanyagot (azaz nagyobb mértékủ amiloid lerakódást) jeleznek. (A kép Creative Commons 4.0 [CC BY 4.0] licenc [http://creativecommons.org/licenses/by/4.0] alatt áll; López-de-Eguileta et al. 2020 alapján, a feliratok és az elrendezés változtatásával.)

rán mért kóros fehérjelerakódás mértéke és területi eloszlása (1. ábra), illetve az agy-gerincvelői folyadékban mért koncentrációja a béta-amiloid 42 aminosavból álló változatának (Aß42), mely forma nagymértékben jelenik meg a plakkokban (Milà-Alomà-Suárez-Calvet-Molinuevo 2019; Schindler-Bateman 2021). Az A 342 koncentrációja az agy-gerincvelői folyadékban a betegség progressziójának korai szakaszán tetőzik, és utána csökkenést mutat az agyban történő aggregációja következtében, ezért alkalmas lehet a betegség korai azonosítására és a kognitív hanyatlás progressziójának becslésére. Mivel a béta-amiloid keletkezésében előfordulnak egyének közötti eltérések, az A 342 és az Alzheimer-kórban érintetlen 40 aminosavból álló $A \beta 40$ agy-gerincvelői folyadékban mért aránya is gyakran elfogadott biomarkernek minősül (Milà-Alomà-Suárez-Calvet-Molinuevo 2019; Zetterberg-Blennow 2020). Míg az agy-gerincvelői folyadékban mért béta-amiloid biomarkerek hamarabb információt adnak az Alzheimer-patológiáról, mint ahogyan PET-vizsgálattal detektálni lehetne a plakkokat (MilàAlomà-Suárez-Calvet-Molinuevo 2019), a PET elönye, hogy képet ad a kóros fehérjelerakódás elhelyezkedéséról az agyban, ezáltal információt szolgáltatva a betegség stádiumáról, továbbá lehetővé téve az egyéb, hasonló klinikai tüneteket eredményező betegségek kizárását, valamint az Alzheimer-kór atípusos formái esetén a megfelelő variáns azonosítását, hozzájárulva mindezzel a terápiás lehetőségek személyre szabásához (Chételat et al. 2020).

A tau fehérje esetében a neurofibrilláris kötegeket megjelenítő PET-vizsgálat eredménye és az agy-gerincvelői folyadékban mért foszforilált-tau ( $p$-tau) koncentrációja minősülnek a legelterjedtebb biomarkernek (Milà-Alomà-Suárez-Calvet-Molinuevo 2019; Zetterberg-Blennow 2020). Az agy-gerincvelői folyadékban mért p-tau egyéb betegségek során nem, vagy csupán alacsony mértékben növekszik meg, így a p-tau ígéretes biomarkernek minósül az Alzheimer-kór diagnózisában. Jelenleg a p-tau 181 mérése történik meg a leggyakrabban a p-tau biomarkerek közül, mely az Alzheimer-kór progressziója során már a neurofibrilláris kötegek PET segítségével történő detektálását megelőzően információt ad a betegségről (Milà-Alomà-Suárez-Calvet-Molinuevo 2019).

A neurodegeneráció legelterjedtebb biomarkerei a strukturális mágneses rezonancia képalkotás (magnetic resonance imaging, $\mathrm{MRI}$ ) során detektált atrófia mértéke (és helye), a $\left[{ }^{18} \mathrm{~F}\right]$-fluorodeoxiglukóz (FDG) jelzőanyagot alkalmazó PET-vizsgálat által detektált hipometabolizmus (anyagcsere-alulmúködés), az agy-gerincvelői folyadékban mért összes tau (t-tau) koncentrációja, és szintén az agy-gerincvelői folyadékban mért neurofilamentum könnyúlánc-fehérje (neurofilament light, NfL) koncentrációja (Milà-Alomà-Suárez-Calvet-Molinuevo 2019).

A neurodegeneráció mértékének indirekt mutatója a csökkent anyagcsere az agyban, melyról a szinaptikus tevékenységet és gliasejt-aktivitást tükröző helyi glükózfogyasztást detektáló FDG PET segítségével lehet képet kapni (Chételat et al. 2020; Grande-Qiu-Fratiglioni 2020). Alzheimer-kór esetén a vizsgálat kétoldali hipometabolizmust mutat a poszterior cinguláris, temporális és parietális területeken (Avvanitakis-Shah-Bennett 2019; Chételat et al. 2020). A módszer előnye, hogy képes információt adni arról, hogy a vizsgálatot követő néhány éven belül lehet-e számítani a betegség progressziójára (Chételat et al. 2020). A tau fehérje a neuronok károsodásának következtében szivárog be az agy-gerincvelői folyadékba (Zetterberg-Blennow 2020), ahol megnövekedett koncentrációja Alzheimer-kórban a betegség 
intenzitásáról, az agykérgi károsodás mértékéről ad tájékoztatást (Milà-Alomà-Suárez-Calvet-Molinuevo 2019; Zetterberg-Blennow 2020). Az NfL koncentrációja az agy-gerincvelői folyadékban az idegsejt axonjának károsodása következtében emelkedik meg, kéreg alatti és gerincvelői degenerációnál egyaránt. Ez számos betegség esetén bekövetkezhet, így az NfL a neurodegeneráció független és általános biomarkereként említhető, mely segítséget nyújthat a kognitív hanyatlás bekövetkeztének megjóslásában (Milà-Alomà-Suárez-Calvet-Molinuevo 2019; Schindler-Bateman 2021; Zetterberg-Blennow 2020).

Az Alzheimer-kórban az Alzheimer-patológián kívül gyakran figyelhető meg egyéb kóros folyamat is, mint például a vér-agy gát integritásának és az agy érhálózatának sérülése, ami az agy energia- és oxigénellátására van hatással (Grande-Qiu-Fratiglioni 2020; Milà-AlomàSuárez-Calvet-Molinuevo 2019). Ezen kívül még kiemelten fontos megemlíteni a központi idegrendszer immunválaszának következtében kialakuló gyulladásos folyamatot, melynek az Alzheimer-kór korai szakaszától fogva komoly hatása van (Milà-Alomà-Suárez-CalvetMolinuevo 2019). Az agyi immunsejtek feltehetően a kórosan felgyülemlett fehérjékre reagálnak gyulladásos válasszal (Serrano-Pozo-Das-Hyman 2021), ami a betegség különböző szakaszaiban eltérő hatást gyakorolhat a betegség progressziójára nézve: míg egy immunreakció szerepet játszhat a lerakódott fehérjék eltávolításában, addig egy hosszú ideig fennálló gyulladási folyamat felgyorsult neurodegenerációt is eredményezhet (MilàAlomà-Suárez-Calvet-Molinuevo 2019).

A biomarker-kutatás az Alzheimer-kór egyik kiemelt kutatási módszerévé vált, és míg az eddig említetteken túl számos egyéb, Alzheimer-kórban érintett biomarkert azonosítottak már a kutatók, említve például a TDP43 fehérjét, az alfa-szinukleint és a VILIP-1 fehérjét, a kutatás az új, ígéretes biomarkerek után jelenleg is zajlik (Milà-Alomà-Suárez-Calvet-Molinuevo 2019).

\section{Mágneses rezonancia képalkotás Alzheimer- kórban}

Az agyról készített strukturális MRI-felvétel nagyban hozzájárul az Alzheimer-kór diagnózisának felállításához, ugyanis lehetóséget ad az egyéb, kognitív tüneteket eredményező betegségek egy részének (pl. agyi tumor, hydrocephalus, vaszkuláris léziók) kizárására, illetve annak a megállapítására, hogy fennáll-e az Alzheimer-patológián kívül egyéb betegség is, ami kevert eredetű demenciához vezet. Az Alzheimer-kór során fellépó neurodegeneratív folyamatokat - mint az idegsejtek morfológiai változása, sérülékenységük növekedése, kapcsolatrendszerük ritkulása, a szinaptikus diszfunkció és a progresszív sejtvesztés - a strukturális felvételen az agy állományának csökkenése, vagyis az atrófia tükrözi (Ashton et al. 2020; Grande-Qiu-Fratiglioni 2020) (2. ábra). Az atrófia komoly változásokat idéz elő az agy egészének szerkezetében, a különböző régiók struktúrájában, az agyi szövet denzitásában, az agykéreg vastagságában (Rathore et al. 2017). Az atrófia mértéke kritikus információval szolgál a betegség súlyosságáról és előrehaladottságáról (Zetterberg-Blennow 2020), az atrófia topográfiai mintázata pedig összefüggést mutatva a kognitív tünetekkel hozzájárul az Alzheimer-kór altípusainak azonosításához.

Típusos Alzheimer-kór esetén az atrófia elsőként a mediális temporális kéregben figyelhető meg (különös tekintettel a hippokampuszra), ezt követően pedig fokozatosan, a klinikai tünetek progressziójával párhuzamo-

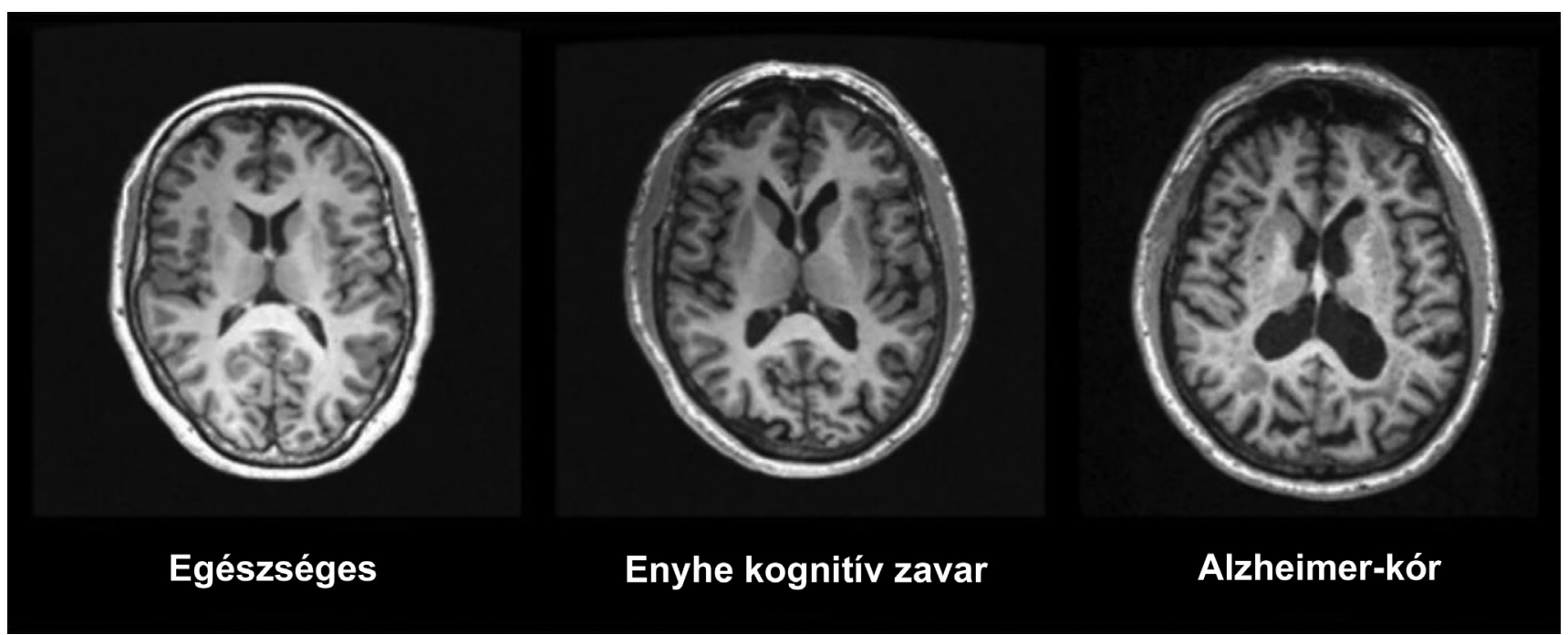

2. ábra

Strukturális, Tl-súlyozott, MPRAGE (Magnetisation Prepared Rapid Gradient Echo) MRI-felvételek egészséges, enyhe kognitív zavarral, valamint Alzheimer-kórral diagnosztizált személyekről. A demencia előrehaladtával a szürkeállomány térfogatának fokozatos csökkenése figyelhető meg. (A kép Creative Commons 4.0 [CC BY 4.0] licenc [http://creativecommons.org/licenses/by/4.0] alatt áll, Chandra et al. 2019 alapján, a feliratok változtatásával.) 
san válik megfigyelhetővé a temporoparietális régiókban. Az Alzheimer-kór atípusos formáinál a poszterior variáns esetében az okcipitoparietális és poszterior temporális régiók károsodása figyelhetô meg a strukturális felvételeken. A logopéniás változatot a Sylvius-árok körüli poszterior terület és a parietális kéreg atrófiája jellemzi, a frontális variáns esetében pedig temporoparietális atrófia figyelhető meg a frontális szürkeállomány relatív megtartottsága mellett, ami miatt a frontális variáns megnevezést kiváltandó viselkedéses-diszexekutív variáns megnevezés is jelen van a szakirodalomban. Az elmúlt években a strukturális méréseken kívül az agyi régiók közötti öszszeköttetések vizsgálata is széles körben elérhetővé vált. Mivel a strukturális és funkcionális kapcsolatok mintázata és erőssége is jelentősen változik Alzheimer-kórban, az ezen kapcsolatokat vizsgáló diffúziós MRI (diffusion tensor imaging), illetve nyugalmi állapotban mért funkcionális MRI további hasznos információkkal szolgálhat a betegség lefolyásáról, típusáról. Alzheimer-kórban az agyi alapállapotú hálózat (default mode network) csökkent konnektivitása figyelhető meg, mellette pedig poszterior variáns esetén a vizuospaciális hálózat, logopéniás variáns esetén a nyelvi hálózat, és frontális variáns esetén a frontoparietális hálózat megváltozott konnektivitása van jelen (Elahi-Miller 2017; Rathore et al. 2017).

Ezen okokból kifolyólag, és az MRI egyre szélesebb körökben való rendelkezésre állása miatt a strukturális képalkotás a betegség klinikai azonosításának szerves részét képezi (Schindler-Bateman 2021). Továbbá, az Alzheimer-diagnózis felállításához elvégzendő vizsgálatok sorrendjére javaslatot tevő, nemzetközi szakértőkboól álló munkacsoport a strukturális képalkotó vizsgálatot a kognitív állapotfelmérés utáni első helyre rangsorolta, és elvégzését még a többi biomarker tesztelését megelőző lépésként javasolta (Chételat et al. 2020).

\section{A betegség etiológiája}

Az Alzheimer-kór leggyakoribb, sporadikus formáját több patológiás folyamat súlyosbodása kíséri, azonban mind a mai napig ismeretlen, hogy a betegség progreszszióját mi váltja ki, és a különböző neurodegeneratív folyamatok jelentkezésének idői sorrendje is vitatott (Arnsten et al. 2021; Hampel et al. 2018). A betegség etiológiáját illetően egészen mostanáig az amiloidelmélet volt a legáltalánosabb elképzelés, amely azt feltételezi, hogy a béta-amiloid felgyülemlése jelenti a betegség kiindulópontját, és ezt követi a tau patológia, majd a neurodegeneráció további folyamatai, melyek következtében a kóros folyamat végén megjelenik a kognitív hanyatlás. A béta-amiloid plakkok képződése már felnőttkorban megjelenik, és a hanyatlás évtizedek alatt megy végbe (Mortamais et al. 2017; Snitz-Brickman 2020). A korábban megállapított biomarkerek egyre pontosabb detektálásának és elterjedtebb alkalmazási lehetőségeinek köszönhetően az amiloidelmélet megkérdőjeleződött, ugyanis több kutatócsoport talált olyan
Alzheimer-kórhoz vezetô patológiát, amely már a szenilis plakkokat megelőzően jelen volt a szervezetben. Erre példa a vaszkuláris hipotézis (mely szerint az agyi vaszkuláris diszfunkció az első lépése az Alzheimer-kórhoz vezető folyamatnak), az a felvetés, amely a gyulladást azonosítja a kaszkád első lépcsőfokaként, és a tau hipotézis, amely azt feltételezi, hogy az elsőként megjelenő kórosan foszforilált tau indítja be a béta-amiloid aggregációt, és a két folyamat egymás hatását kölcsönösen tovább növelve vezet a kognitív hanyatláshoz, amely folyamatot a környezeti és genetikai hatások még tovább gyorsítják (Arnsten et al. 2021; Grande-Qin-Fratiglioni 2020). Habár a folyamatot indukáló tényezó további vita tárgyát képezi, a különböző elméletek többségében közös a megfigyelés, hogy az Alzheimer-kór hátterében álló biológiai folyamatok a kognitív tünetek megjelenése előtt már évekkel, évtizedekkel megjelennek, mely a betegség korai diagnosztikai lehetőségének új távlatához vezet (Mortamais et al. 2017).

\section{Út a korai diagnózis felé}

A jelenlegi kutatások az Alzheimer-kór három szakaszát azonosítják: (1) a preklinikai szakaszt, amikor már mérhető változások lépnek fel az Alzheimer-kór során azonosított biomarkerekben, de még nem alakultak ki a kognitív tünetek, (2) az Alzheimer-kór miatti enyhe kognitív zavar (mild cognitive impairment) szakaszát, amely során a betegek kogníciója az életkorukban várhatónál nagyobb mértékú romlást mutat, viszont ez nem befolyásolja jelentősen a mindennapi tevékenységek elvégzését, és (3) az Alzheimer-kór okozta demencia szakaszát, melyben a kognitív tünetek már markánsan jelen vannak, és a hétköznapi életet akadályozzák (Albertet al. 2011; Alzheimer's Association 2019; Jack et al. 2011; McKhann et al. 2011; Roberts-Knopman 2013; Sperling et al. 2011). A 65 év felettiek körülbelül 15-20 százaléka érintett enyhe kognitív zavarban bármilyen kiváltó okból (Roberts-Knopman 2013), és a 65 évnél idősebb enyhe kognitív zavarban érintett betegek 15 százalékánál alakul ki demencia 2 éven belül (Petersen et al. 2018) és 32 százalékánál 5 éven belül (Mitchell-Shiri-Feshki 2009).

A terápiás lehetôségeket övező intenzív nemzetközi kutatási érdeklődés ellenére jelenleg nincs olyan gyógyszer, amely az Alzheimer-kórt igazoltan gyógyítaná (Goetzl 2020; Grande-Qiu-Fratiglioni 2020; SchindlerBateman 2021). A terápia jelenleg fóként a demencia kognitív és viselkedéses tüneteinek enyhítésére fókuszál (Arvanitakis-Shab-Bennett 2019; Livingston et al. 2020), azonban számos kutatás igyekszik feltárni a prevenciós és intervenciós lehetőségeket, melyek a betegség progressziójának lassítását célozzák. Ennek kulcsa, hogy a beavatkozás a lehető legkorábban, még a preklinikai szakaszban megtörténjen (Grande-Qiu-Fratiglioni 2020; Schindler-Bateman 2021). Az ehhez köthető számos kihívás közül az egyiket az jelenti, hogy az érintettek általában akkor fordulnak először orvoshoz, amikor 
már tapasztalták magukon a kognitív változásokat, a preklinikai szakaszt követöen (Arvanitakis-Shab-Bennett 2019).

A biomarkerek egyre szélesebb körben elérhető alkalmazhatóságának köszönhetően az elmúlt években lehetőség nyílt az Alzheimer-kór már a preklinikai szakaszban jelen lévő markereinek korai vizsgálatára. A számos előny mellett azonban mind a PET-vizsgálatnak, mind pedig az agy-gerincvelői folyadék mintavételének megvannak a hátrányai is, amelyek miatt a mindennapi klinikai gyakorlatban alacsony az alkalmazhatóságuk (Schindler-Bateman 2021). Annak ellenére, hogy viszonylag alacsony a procedúra kedvezőtlen kimenetelének aránya, az agy-gerincvelői folyadék kinyerése invazív eljárásnak minősül, továbbá nem szolgáltat információt az agyi degeneratív folyamatok topográfiájáról (Chételat et al. 2020; Milà-Alomà-Suárez-Calvet-Molinuevo 2019). Ezzel szemben PET-vizsgálattal detektálható a fehérjék felhalmozódásának helye, azonban a mérés szintén invazív, kevés helyen elérhető, és nem utolsósorban drága: Chételat és munkatársai 2020-as cikkükben az amiloid PET-vizsgálat árát 2000 és 2500 euró közötti összegre becsülték (Chételat et al. 2020; Hampel et al. 2018). Ebből kifolyólag, míg az említett vizsgálatok indokolt esetben elvégezhetők, nem ideálisak arra, hogy a demencia széles körü, korai szürésére alkalmazzák őket.

A közelmúltban számos erófeszítést tettek a kutatók arra, hogy egyéb, könnyen elérhető biológiai mintákból (pl. vér, nyál, vizelet) nyerjenek ki biomarkereket (MilàAlomà-Suárez-Calvet-Molinuevo 2019). A kutatás legígéretesebb eredményének az Alzheimer-kórban érintett biomarkerek vérből történő kinyerése tünik. Azonban a módszer komoly kihívást jelent, ugyanis a vérben alacsonyabb a legtöbb Alzheimer-kórban implikált biomarker koncentrációja, mint az agy-gerincvelői folyadékban. Ennek a problémának az áthidalását a nagyon magas érzékenységet mutató mérések kidolgozása jelentette (Schindler-Bateman 2021), aminek következtében egyre megbízhatóbban lehet NfL-t, A 342 - $t, A \beta 42 / A \beta 40$ arányt, p-tau 181-et, t-tau-t mérni, és ígéretes kutatások látnak napvilágot a p-tau egyéb izoformáinak méréséról is (Schindler-Bateman 2021; Zetterberg-Blennow 2020).

A biomarkerek hasznossága vitathatatlan, azonban nem a biomarker kutatás az egyetlen út, amelyen a kutatók elindultak a demencia korai felismerése felé. Izgalmas kérdést jelent például az, hogy amennyiben az egyén érzi magán a kognitív hanyatlás tüneteit, azonban a kognitív funkciók objektív teszteken nem mutatnak romlást, az vajon előre jelezheti-e a demencia kialakulását. Az idősebb felnőttek körülbelül 20-25 százalékánál jár együtt az öregedés fokozott memóriapanaszokkal (Jonker-Geerlings-Schmand 2000). A memóriapanaszok számos egyéb betegséghez, állapothoz kapcsolódhatnak (például szubklinikai pszichiátriai tünetekhez, vagy akár stressz okozta figyelmetlenséghez is), ugyanakkor lehetnek akár a demencia korai jelei is, beleértve az Alzheimer-kórt (Jessen et al. 2010; Jonker-Geerlings-Schmand
2000; McWhirter et al. 2020; Mitchell et al. 2014; ReidMacLullich 2006; Slot et al. 2019). Gyakori, hogy az idősek tartósan úgy érzik, hogy emlékezetük és gondolkodásuk rosszabb, mint korábban (Jessen et al. 2014). A neuropszichológiai teszteken mért megőrzött - az Alzheimer-kór vagy enyhe kognitív zavar diagnosztikai feltételeit nem kimerítő - jó teljesítmény, valamint a megőrzött napi múködés és függetlenség ellenére tapasztalt memóriapanaszokra napjainkban a szubjektív memóriazavar (subjective memory impairment) állapotaként hivatkoznak a klinikusok (Jessen et al. 2010). Habár erősen vitatott, hogy a szubjektív memóriazavar mennyire képes megjósolni az enyhe kognitív zavar vagy az Alzheimer-kór kialakulását, egyesek szerint a jelenség az Alzheimer-kór preklinikai szakaszára utalhat (Jack et al. 2018; Sperling et al. 2011).

\section{Pontosabb diagnózis és progresszióbecslés mesterséges intelligencia segítségével}

Annak ellenére, hogy a szubjektív memóriapanaszok értékes információval szolgálhatnak az Alzheimer-kór jövőbeni progressziójának becslésekor, kiemelten fontos megjegyezni, hogy nem minden személynél alakul ki demencia, aki kognitív panaszokat észlel magán (Ellis et al. 2009; McWhirter et al. 2020). Ugyanígy, azt is hangsúlyozni kell, hogy önmagában az, hogy valakinél az Alzheimer-kórra jellemző biomarkerek mérhetően jelen vannak, még nem jelenti azt, hogy biztosan kialakul nála a kognitív hanyatlás (Bennett et al. 2006; Bilgel-Resnick 2020; Knopman et al. 2003; Schindler-Bateman 2021). Emiatt egyre inkább kezd elterjedni az az irányzat, hogy a betegséget holisztikusan kell szemlélni, és több biomarker, valamint a betegségre hajlamosító genetikai és környezeti faktorok együttes hatását figyelembe véve érdemes becslést adni a betegség kimenetelére (Lamb et al. 2021; Schindler-Bateman 2021). Mivel az Alzheimer-patológia következtében kialakuló kognitív tünetek azok, amik az egyén boldogulását akadályozzák a hétköznapi életben, és mivel a kogníció változása a leginkább indikatív a betegség progressziójára nézve (Snitz-Brickman 2020), kiemelten fontos az olyan kognitív tesztek fejlesztése és alkalmazása, melyek elég szenzitívek ahhoz, hogy a kisebb mértékü, korai kognitív tüneteket is detektálják (Mortamais et al. 2017), továbbá a teszteredmények figyelembevétele a betegség vizsgálatánál. Ennek megfelelően egyre több kutatás kombinál fehérjemarkereket, kognitív pontszámokat és agyi képalkotásból származó információkat azzal a szándékkal, hogy feltárja a különböző markerek idői megjelenését és hozzájárulását a betegség lefolyásához, ezzel elősegítve a pontosabb diagnózist a preklinikai szakaszban (Ashton et al. 2020; Mortamais et al. 2017). A pontos becsléshez matematikai modellalkotás szükséges, mely által összehasonlíthatóvá válik az, hogy az egyes rendelkezésre álló vizsgálati értékek melyik szakaszban, és milyen kombinációkban alkalmasabbak a betegség jóslására. Erre kiváló példával 
szolgálnak azok a közelmúltban megjelent kutatási eredmények, melyek szerint egy biomarker figyelembevételével szemben több biomarkert együttesen vizsgálva sikeresebben szétválaszthatóak az egyes betegcsoportok (Hampel et al. 2018), így például a vérplazmából mért p-tau 181 koncentrációja és az NfL szintje együttesen jósolta be a legsikeresebben, hogy 4 év leforgása alatt az enyhe kognitív zavar Alzheimer-típusú demenciává alakul-e (Cullen et al. 2021; Schindler-Bateman 2021).

Arra, hogy az egyes személyekről gyújtött nagy menynyiségú mért adatból értékes információkat lehessen kiszúrni, a mesterséges intelligenciával támogatott adatelemzési eljárások jelentik a jövôt. Korábbi kutatások például gépi tanulási modellek segítségével képesek voltak jó pontosságú becslést adni arra, hogy az enyhe kognitív zavarral diagnosztizált betegek állapota stabil marad-e, vagy romlást fog mutatni (Rathore et al. 2017). Egy ígéretes új kutatás pedig egészséges, illetve enyhe kognitív zavarral diagnosztizált személyek első vizsgálatakor mért kognitív és biológiai mérőszámok alapján határozta meg a személyek egyéni profiljait és jósolta be gépi tanulás segítségével a kognitív állapot változásának egyéni pályáit (Giorgio et al. 2020).

Az Agyi Képalkotó Központ (AKK) ezen a területen a közelmúltban több áttörő eredményt is elért. Egy korábbi kutatásban az AKK munkatársai abból a felfedezésből indultak ki, hogy a nyugalmi állapotban - funkcionális MRI-vel - mért agyterületek közötti funkcionális kapcsolatok erőssége alkalmas lehet arra, hogy jellemezze a különböző neuropszichiátriai betegségek agyi folyamatait. Mivel a képfeldolgozás területén (beleértve az orvosi képalkotást is) áttörést hozott a mesterséges intelligencia használata, azon belül is a konvolúciós neurális hálók alkalmazása, munkatársaink ezt a módszert adaptálták a funkcionális konnektivitási mátrixok osztályozására, és segítségével képesek voltak az egészséges idős és enyhe kognitív zavarban szenvedő betegek elkülönítésére, pusztán a funkcionális agyi hálózati aktivitásuk alapján (Meszlényi-Buza-Vidnyánszky 2017). Másik jelentős kutatásunk során munkatársaink azt vették figyelembe, hogy az agyi kapcsolati mintázatok erőssége változik az életkorral. Mesterséges intelligencia segítségével megbecsülhető az egyén életkora az agyi kapcsolati mintázata alapján. Az agyi képalkotással nyert felvételek alapján becsült és a tényleges életkor közötti eltérés az agyi öregedés ígéretes biomarkere, mely összefüggést mutat a neurodegeneratív megbetegedések kialakulásának kockázatával (Cole-Franke 2017). Munkatársaink kimutatták, hogy a megfelelő transzfertanulási módszerek alkalmazásával a funkcionális kapcsolatok erősségén alapuló agyéletkorbecslés pontossága nagymértékben javítható akkor is, ha viszonylag kevés felvétel áll rendelkezésre a neurális hálózatok tanításához, ezáltal jelentôsen hozzájárulva a kóros agyi folyamatok hatékony előrejelzéséhez (Vakli et al. 2018).

Amellett, hogy a mesterséges intelligencia alapú modellezés hozhatja meg az áttörést az Alzheimer-kór etio- lógiájának, korai diagnózisának és személyre szabott terápiás megoldásainak feltárásában, alkalmazása számos etikai és biztonsági vonatkozást felvet. Mivel az egyének életmódjáról, genetikájáról, szellemi teljesítóképességérő́l és fiziológiájáról gyújtött adat kiemelten szenzitív információnak minősül, az adatok begyújitése és kezelése kiemelt körültekintésre inti a kutatókat, és magas fokú adatbiztonsági intézkedéseket igényel. Ennek érdekében a különböző nemzetközi adatbankok szigorú előírásokat támasztanak annak kapcsán, hogy ki és milyen formában férhet hozzá a kísérleti adatokhoz, továbbá hogy az adatok tárolása minden esetben anonimizáltan történjen, és hogy minden, mintában szereplő személy bármikor tudja érvényesíteni a jogát, hogy az adatainak tárolására korábban adott engedélyét visszavonja (Ienca-VayenaBlasimme 2018). Az is komoly etikai kérdéseket vet fel, hogy a betegség korai - jóval a tünetek megjelenése előtt felállított - diagnózisa hogyan befolyásolja az egyén életútját. Míg a korai diagnózis egyértelmú előnye, hogy hatékonyan megtervezhetővé válik általa a személy késóbbi ellátása, a diagnózis sok esetben stigmatizáló hatással járhat együtt, valamint szorongást és aggodalmat válthat ki, ami különösen korai diagnózis esetén hosszú időn át kíséri végig - az adott esetben még évekig teljesen tünetmentes - személyeket (Chételat et al. 2020).

\section{Terápiás irányok}

A demencia nagymértékú egyéni és társadalmi terheinek (Nichols et al. 2019) fényében kiemelt fontosságú a betegség megelőzése és kezelése. Bár számos kutatás foglalkozik a demencia hátterében álló patológiás élettani folyamatok feltérképzésével és azok befolyásolásának lehetőségeivel, sajnos jelenleg nem áll rendelkezésre olyan gyógyszer, amivel érdemben be lehetne avatkozni a betegség sokkomponensû patológiás folyamatába, és az elmúlt évtizedekben számos gyógyszerkutatás bizonyult eredménytelennek (Gauthier et al. 2016). Mindazonáltal számos új kutatási irány körvonalazódik, melyek közül az egyik legígéretesebb az epigenom változásait célzó gyógyszerek fejlesztése, annak reményében, hogy általuk visszafordíthatóvá válnak a génexpresszióban bekövetkezett patológiás változások (Xiao-Lin-Jiao 2020). A gyógyszeres kezelés mellett a kognitív funkciók fenntartását célzó terápiák (Babar-Fuchs et al. 2019) és az életmód-intervenciók (Kivipelto-Mangialasche-Ngandu 2018) területén is jelentős eredmények érhetóek el. A demencia diagnózisát követóen átfogó kezelési terv ajánlott, mely érinti a fizikai és mentális egészséget, valamint a szociális kapcsolatokat is (Livingston et al. 2020). $\mathrm{Az}$ orvostudomány legkurrensebb intervenciós modelljét követve az ideális megelőzési és kezelési terv személyre szabható (Isaacson et al. 2019).

A precíziós orvoslás (precision medicine) keretrendszere a kezelési tervet az egyéni tüneti képnek, életmódnak és igényeknek megfelelően határozza meg (Hodson 2016). A populációs adatok alapján felállított előrejelzé- 
sek mentén az intervenciók személyre szabhatóak lehetnek. A megbízható predikcióhoz nagyszámú populációs adat szükséges: vérből és agy-gerincvelői folyadékból kimutatott biomarkerek, agyi képalkotás (MRI, PET), neuropszichológiai státusz, információk egyes életmódbeli és környezeti tényezőkről. A különböző kockázati és protektív tényezók ismeretében az egyénre jellemző paraméterek mentén elörejelezhető lehet a betegség lefolyása, valamint az egyes intervenciók várható hatása. A személyre szabott kezelési lehetőségek közül kiemelendőek az agyi stimulációs módszerek, melyek ígéretes kutatási irányt jelentenek a demenciában megjelenő kognitív tünetek kezelésében (Buss-Fried-Pascual-Leone 2019).

A transzkraniális agyi stimuláció a hajas fejbőrre helyezett elektródákon keresztül gyenge elektromos impulzusokkal modulálja az agykéreg idegsejtcsoportjainak elektromos aktivitását (Antal-Herrmann 2016). A különböző kognitív funkciók (emlékezet, figyelem, végrehajtó funkciók) hátterében álló neurofiziológiai folyamatok modulációjával a demenciával járó kognitív deficitek javíthatóak lehetnek (Moussavi et al. 2021). Az agyi sti- mulációs módszerek egy formája a transzkraniális váltóáramú stimuláció (transcranial alternating current stimulation), mellyel meghatározott agykérgi területek frekvenciaspecifikusan stimulálhatóak (Herrmann et al. 2013). Az intervenció az egyénre jellemző frekvenciasávok meghatározásával a precíziós orvoslás keretrendszerével összhangban személyre szabható (Herrmann et al. 2013).

A demencia egyes rizikófaktorai (életkor, nem, genetikai prediszpozíció) nem módosíthatóak, míg mások - így az életmódbeli és környezeti kockázati tényezők hatásán, célzott intervencióval változtatni lehet (Licher et al. 2019). A cél, hogy a módosítható rizikófaktorok mentén már az első tünetek megjelenése előtt sor kerüljön a demencia kialakulását késleltető vagy akár meg is akadályozó beavatkozásra. A precíziós orvoslási megközelítésnek megfelelően a megelőzési terv is személyre szabható lehet (Isaacson et al. 2018). A megelózést nem lehet túl korán elkezdeni; a legfrissebb szakmai konszenzus az élethosszon át tartó megelőzés fontosságát hangsúlyozza (Livingston et al. 2020). A prevenciós intézkedések tehát a teljes életutat felölelik: az élet korai

1. táblázat | A demencia rizikófaktorai és megelőzési lehetőségeik (Livingston et al. 2020 alapján saját szerkesztés)

\begin{tabular}{|c|c|}
\hline Rizikófaktor & Lehetséges megelőzési intézkedések \\
\hline Alacsony iskolázottság & $\begin{array}{l}\text { Az oktatásnak a korai életszakaszban van kiemelt jelentősége, ám középkorú és idős felnőttek esetében is protek- } \\
\text { tív tényező́t jelenthet a kogníció fenntartása szellemi tevékenységekkel (zene, olvasás, utazás, idegen nyelvek, } \\
\text { társasági élet). }\end{array}$ \\
\hline Hallászavarok & $\begin{array}{l}\text { A hallászavarok, különösen középkorúak esetében, kiemelt kockázatot jelentenek a demenciára nézve. A hallóké- } \\
\text { szülékek használatának elősegítésével ez a kockázat kezelhető. }\end{array}$ \\
\hline Traumás agysérülés & $\begin{array}{l}\text { A traumás agysérülés kiterjedt hiperfoszforilált tau-patológiával járhat, így kockázatot jelent a demenciára nézve. } \\
\text { Megfelelő biztonsági intézkedésekkel a balesetből fakadó agysérülések megelőzhetőek lehetnek. }\end{array}$ \\
\hline Magas vérnyomás & $\begin{array}{l}\text { A középkorú felnőtteknél hosszú távon fennálló magas vérnyomás ( } 130 \text { Hgmm vagy annál magasabb szisztolés } \\
\text { vérnyomás) összefügggést mutat az időskori demencia kialakulásával. A rizikó vérnyomáscsökkentő gyógyszerek- } \\
\text { kel csökkenthető. Több szív- és érrendszeri betegség egyidejü fennállása kiemelt kockázatot jelenthet. }\end{array}$ \\
\hline Túlzott alkoholfogyasztás & $\begin{array}{l}\text { A túlzott alkoholfogyasztás idegrendszeri változásokkal, kognitív hanyatlással és demenciával járhat. A legfrissebb } \\
\text { ajánlások a heti } 21 \text { egység vagy annál több alkohol fogyasztását emelik ki, mint fokozott kockázati tényezőt. }\end{array}$ \\
\hline Elhízás & $\begin{array}{l}\text { Számos kutatás mutatott ki összefüggést a magas testtömegindex és a demencia között, kiemelten a kóros elhízás } \\
\text { (obezitás) jelent rizikót. Az egészséges étkezés feltehetőleg a szív- és érrendszeri betegségek, valamint az elhízás } \\
\text { megelőzésén keresztül jelent védőfaktort a demenciával szemben. Az Egészségügyi Világszervezet (WHO) a } \\
\text { mediterrán diétát javasolja a kognitív hanyatlás és a demencia megelőzésének céljából (World Health Organization } \\
\text { 2019). A táplálékkiegészítők prevencióban betöltött szerepét a vonatkozó kutatások nem támasztják alá (Rutjes } \\
\text { et al. 2020). }\end{array}$ \\
\hline Dohányzás & A dohányzás növeli a demencia kockázatát, abbahagyása csökkenti ezt a rizikót. \\
\hline Depresszió & $\begin{array}{l}\text { A depresszió összefügg a demencia előfordulásával, a demencia korai stádiumára jellemző. Kérdés, hogy a dep- } \\
\text { resszió oki tényezóként áll-e a fokozott demenciarizikó mögött, vagy a depresszió a korai stádiumú, még tünet- } \\
\text { mentes demencia következményeként alakul ki. A depresszió kezelése csökkentheti a demencia kockázatát. }\end{array}$ \\
\hline Társas elszigeteltség & $\begin{array}{l}\text { A társas kapcsolatok protektív tényezőt jelentenek, hozzájárulnak a kognitív tartalékok felépítéséhez. A sok társas } \\
\text { kontaktus jobb időskori kognitív funkciókkal jár együtt, és mérsékelten ugyan, de csökkentheti a demencia koc- } \\
\text { kázatát. }\end{array}$ \\
\hline Alacsony fizikai aktivitás & $\begin{array}{l}\text { A sportolás, fizikai aktivitás csökkentheti a demencia kockázatát. A prodromális demencia a sportolás abbahagyá- } \\
\text { sával járhat, mely kiemelt kockázatot jelenthet a szív- és érrendszeri betegségekre nézve. }\end{array}$ \\
\hline Légszennyezettség & $\begin{array}{l}\text { A légszennyezettség egészségügyi kockázatot jelent: a levegót szennyezó részecskék szív- és érrendszeri folyama- } \\
\text { tokon keresztül hozzájárulhatnak a neurodegenerációhoz. A légszennyezettség csökkentése társadalmi szintú } \\
\text { intézkedéseket igényel. }\end{array}$ \\
\hline Cukorbetegség & $\begin{array}{l}\text { A kettes típusú cukorbetegség időtartamával és súlyosságával növekszik a demencia kockázata; kiemelt fontos- } \\
\text { ságú tehát a diabétesz megelőzése. }\end{array}$ \\
\hline
\end{tabular}


szakaszában (45 éves kor alatt) a kognitív tartalékok felépítése, középső (45-65 év) és késői (65 éves kor felett) felnőttkorban pedig a patológiás neurális folyamatok késleltetése és a kognitív erőforrások védelme a cél. Ennek megfelelően egyes prevenciós intézkedések a kognitív erőforrásokat célozzák (oktatás elérhetővé tétele, szellemi aktivitás megörzése), míg mások az idegrendszer patológiás folyamatait igyekeznek megelőzni vagy legalábbis késleltetni (elhízás, kettes típusú cukorbetegség, magas vérnyomás megelőzése és kezelése). A különböző kockázati tényezők különböző életszakaszokban válnak hangsúlyossá, és az adott életszakaszban lehet ellenük a leghatékonyabban tenni. Fiatalkorban az alacsony iskolázottság, középkorú felnőttek esetében a magas vérnyomás, az elhízás, a hallászavarok, a traumás agysérülés és a túlzott alkoholfogyasztás, időskorban a dohányzás, a depresszió, az alacsony fizikai aktivitás, a társas elszigeteltség, a kettes típusú cukorbetegség és a magas légszennyezettség jelent kiemelt kockázatot a demencia kialakulásának szempontjából (Livingston et al. 2020).

A prevenció egyéni és társadalmi szinten is intézkedéseket igényel, melyek kiterjedhetnek a teljes populációra, vagy kifejezetten a rizikócsoportba tartozó személyeket célozhatják (Livingston et al. 2020). Kiemelendő, hogy a teljes populációt érintő szúrőprogramok hatékonyságát jelenlegi evidencia nem támasztja alá. Tünetmentes egyének esetében tehát az életmódbeli, környezeti kockázatokról és megelőzési lehetőségeikről való edukációt magában foglaló, társadalmi szintû megelőzési programok bizonyulhatnak a leghatékonyabb népegészségügyi intézkedésnek (Livingston et al. 2020). Az 1. táblázatban, valamint a 3. ábrán Livingston és munkatársai
(2020) tanulmánya alapján az egyes rizikófaktorok mentén kerülnek áttekintésre a lehetséges megelőzési intézkedések, és hogy a módosítható rizikófaktorokba történő beavatkozások milyen mértékben járulnak hozzá a demencia prevalenciájának csökkentéséhez.

\section{Záró gondolatok}

Összegzésül, a technológia fejlődésének és az Alzheimer-kór és egyéb demenciák területén tapasztalt töretlen kutatási lelkesedésnek köszönhetően egyre több ismeret áll rendelkezésre a betegség oki tényezőiről, melyből a személyre szabott terápiás eljárások kidolgozása, és a gyógyszerfejlesztés is nagyban profitál. Továbbá, a rizikótényezők és protektív faktorok azonosítását célzó kutatások eredményei alapján fontos kiemelni egyrészről azt, hogy a demencia nem az öregedési folyamat szükségszerű velejárója vagy elkerülhetetlen következménye (Fratiglioni-Marseglia-Dekhtyar 2020; Grande-QiuFratiglioni 2020), másrészről pedig azt, hogy az aktív életmód és a stimuláló hétköznapi tevékenységekben való részvétel hozzájárul a szellemi egészség megőrzéséhez, amit sosincs késő elkezdeni.

Sajnálatos módon, a demenciával kapcsolatos hazai kutatás-fejlesztés és betegellátás területén egyaránt nagyon jelentős a lemaradás a fejlett nyugati országokhoz képest. Ezt orvosolandó, egy országos összefogás keretén belül, a hazai demenciakutatás vezető múhelyeinek részvételével létrehozásra került egy Demencia Prevenció kutatás-fejlesztési platform (https://demenciaplatform.hu). A platform célja, hogy lehetôséget biztosítson a demencia különböző típusainak hátterét képező kóros

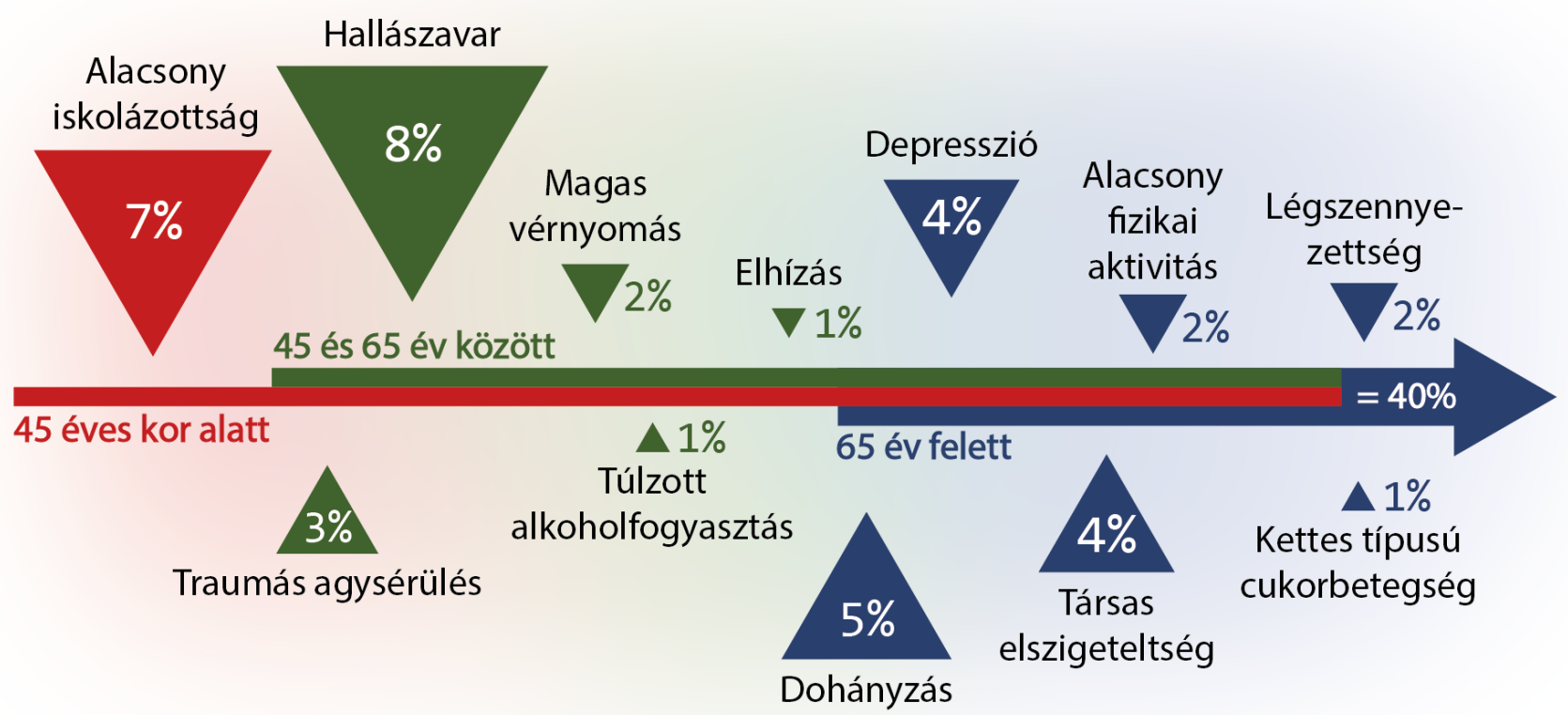

3. ábra A demencia módosítható rizikófaktorai az életút során. A százalékok a demencia prevalenciájának csökkenését jelzik az adott rizikófaktor megszünte-
tése esetén. A színek azt az időintervallumot jelölik, amelyen belül az adott rizikófaktornak igazoltan szerepe van a demencia prevalenciájának csök-
kentésében. Az egyes életszakaszokon belül a különbözó rizikófaktorok ábrázolásának sorrendje nem tükröz időbeli sorrendiséget (Livingston et al.
2020 alapján saját szerkesztés) 
agyi folyamatok és a hajlamosító tényezők kutatására, a betegség mesterséges intelligenciával támogatott korai diagnózisára, a prognózis megítélésére és személyre szabott terápiás eljárások fejlesztésére. A tervezett $\mathrm{K}+\mathrm{F}$ és innovációs tevékenység eredményeként Magyarországon először kerül kialakításra egy olyan demencia-referenciaadatbázis és diagnosztikai keretrendszer, mely megfelel a legmagasabb nemzetközi standardoknak. A mesterséges intelligencia alapú módszerek finomhangolásában kiemelten fontos, hogy minél több adat álljon rendelkezésre, mely tükrözi az Alzheimer-kórban eddig azonosított fontos szereppel bíró különböző változók gazdagságát. A Demencia Prevenció platform keretében létrehozandó multimodális referencia-adatbázis magyar lakosságon mért kognitív, biomarker, genetikai és agyi képalkotás adatokra épül, ami különösen fontos, mert a korábbi nemzetközi, a demencia kialakulását vizsgáló nagyszabású, multimodális vizsgálatokból a kelet-középeurópai régió lakosságára vonatkozó adatok hiányoznak, annak ellenére, hogy a környezeti hatások nagyban beleszólnak a betegség lefolyásába. A betegség feltérképezését az is nagyban segíti, ha a vizsgált személyek többszöri mérésen vesznek részt, longitudinális adatokat szolgáltatva ezzel a demencia idői változásáról, ami nagyban hozzájárul a betegségutak személyre szabott feltérképezéséhez, és célzott terápiák létrehozásához (Hampel et al. 2018).

\section{Irodalomjegyzék}

Aggarwal, N. T., Wilson, R. S., Beck, T. L., Bienias, J. L., \& Bennett, D. A. (2006) Motor dysfunction in mild cognitive impairment and the risk of incident Alzheimer disease. Archives of Neurology, Vol. 63. No. 12. pp. 1763-1769.

Albert, M. S., DeKosky, S. T., Dickson, D., Dubois, B., Feldman, H. H., Fox, N. C., ... Phelps, C. H. (2011) The diagnosis of mild cognitive impairment due to Alzheimer's disease: Recommendations from the National Institute on Aging-Alzheimer's Association workgroups on diagnostic guidelines for Alzheimer's disease. Alzheimer's and Dementia, Vol. 7. No. 3. pp. 270-279.

Al Mamun, A., Uddin, M. S., Kabir, M. T., Khanum, S., Sarwar, M. S., Mathew, B., ... Ashraf, G. M. (2020) Exploring the promise of targeting ubiquitin-proteasome system to combat Alzheimer's disease. Neurotoxicity Research, Vol. 38. No. 1. pp. 8-17.

Alzheimer's Association. (2019) 2019 Alzheimer's disease facts and figures. Alzheimer's \& dementia, Vol. 15. No. 3. pp. 321-387.

Antal, A., \& Herrmann, C. S. (2016) Transcranial alternating current and random noise stimulation: possible mechanisms. Neural Plasticity, https://doi.org/10.1155/2016/3616807

Appell, J., Kertesz, A., \& Fisman, M. (1982) A study of language functioning in Alzheimer patients. Brain and Language, Vol. 17. No. 1. pp. 73-91.

Arnsten, A. F., Datta, D., Del Tredici, K., \& Braak, H. (2021) Hypothesis: Tau pathology is an initiating factor in sporadic Alzheimer's disease. Alzheimer's \& Dementia, Vol. 17. No. 1. pp. 115-124.

Arvanitakis, Z., Shah, R. C., \& Bennett, D. A. (2019) Diagnosis and Management of Dementia: Review. JAMA, Vol. 322. No. 16 1589.

Ashton, N. J., Hye, A., Rajkumar, A. P., Leuzy, A., Snowden, S., Suárez-Calvet, M., ... Aarsland, D. (2020) An update on bloodbased biomarkers for non-Alzheimer neurodegenerative disorders. Nature Reviews Neurology, Vol. 16. No. 5. pp. 265-284.
Bahar Fuchs, A., Martyr, A., Goh, A. M., Sabates, J., \& Clare, L. (2019) Cognitive training for people with mild to moderate dementia. Cochrane Database of Systematic Reviews, Vol. 3. No. 3.

Balsis, S., Carpenter, B. D., \& Storandt, M. (2005) Personality change precedes clinical diagnosis of dementia of the Alzheimer type. The Journals of Gerontology Series B: Psychological Sciences and Social Sciences, Vol. 60. No. 2. pp. 98-101

Bennett, D. A., Schneider, J. A., Arvanitakis, Z., Kelly, J. F., Aggarwal, N. T., Shah, R. C., \& Wilson, R. S. (2006) Neuropathology of older persons without cognitive impairment from two communitybased studies. Neurology, Vol. 66. No. 12. pp. 1837-1844.

Bilgel, M., \& Resnick, S. M. (2020) Amyloid Positivity as a Risk Factor for Memory Decline and Lower Memory Performance as an Indicator of Conversion to Amyloid Positivity: Chicken and Egg. Biological Psychiatry, Vol. 87. No. 9. pp. 782-784.

Braak, H., Thal, D. R., Ghebremedhin, E., \& Del Tredici, K. (2011) Stages of the pathologic process in Alzheimer disease: age categories from 1 to 100 years. Journal of Neuropathology \& Experimental Neurology, Vol. 70. No. 11. pp. 960-969.

Buss, S. S., Fried, P. J., \& Pascual-Leone, A. (2019) Therapeutic noninvasive brain stimulation in Alzheimer's disease and related dementias. Current Opinion in Neurology, Vol. 32. No. 2. 292

Chandra, A., Dervenoulas, G., \& Politis, M. (2019) Magnetic resonance imaging in Alzheimer's disease and mild cognitive impairment. Journal of Neurology, Vol. 266. No. 6. pp. 1293-1302.

Chételat, G., Arbizu, J., Barthel, H., Garibotto, V., Law, I., Morbelli, S., ... Drzezga, A. (2020) Amyloid-PET and 18F-FDG-PET in the diagnostic investigation of Alzheimer's disease and other dementias. The Lancet Neurology, Vol. 19. No. 11. pp. 951-962.

Cole, J. H., \& Franke, K. (2017) Predicting age using neuroimaging: innovative brain ageing biomarkers. Trends in Neurosciences, Vol. 40. No. 12. pp. 681-690.

Cullen, N. C., Leuzy, A., Palmqvist, S., Janelidze, S., Stomrud, E., Pesini, P., ... Hansson, O. (2021) Individualized prognosis of cognitive decline and dementia in mild cognitive impairment based on plasma biomarker combinations. Nature Aging, Vol. 1. No. 1. pp. 114-123.

Dubois, B., Feldman, H. H., Jacova, C., Hampel, H., Molinuevo, J. L., Blennow, K., ... Cummings, J. L. (2014) Advancing research diagnostic criteria for Alzheimer's disease: the IWG-2 criteria. The Lancet Neurology, Vol. 13. No. 6. pp. 614-629.

Ebenau, J. L., Timmers, T., Wesselman, L. M. P., Verberk, I. M. W., Verfaillie, S. C. J., Slot, R. E. R., ... van der Flier, W. M. (2020) ATN classification and clinical progression in subjective cognitive decline: The SCIENCe project. Neurology, Vol. 95. No. 1. pp. e46-e 58.

Elahi, F. M., \& Miller, B. L. (2017) A clinicopathological approach to the diagnosis of dementia. Nature Reviews Neurology, Vol. 13. No. 8. 457.

Ellis, K. A., Bush, A. I., Darby, D., De Fazio, D., Foster, J., Hudson, P., ... the AIBL Research Group (2009) The Australian Imaging, Biomarkers and Lifestyle (AIBL) study of aging: Methodology and baseline characteristics of 1112 individuals recruited for a longitudinal study of Alzheimer's disease. International Psychogeriatrics, Vol. 21. No. 4. pp. 672-687.

Fitten, L. J., Perryman, K. M., Wilkinson, C. J., Ganzell, S., Randolph Mervis, J., Little, R. J., ... Malmgren, R. (1995) Alzheimer and Vascular Dementias and Driving: A Prospective Road and Laboratory Study. JAMA, Vol. 273. No. 17. pp. 1360-1365.

Fratiglioni, L., Marseglia, A., \& Dekhtyar, S. (2020) Ageing without dementia: Can stimulating psychosocial and lifestyle experiences make a difference? The Lancet Neurology, Vol. 19. No. 6. pp. 533543.

Garre-Olmo, J. (2018) Epidemiology of Alzheimer's disease and other dementias. Revista de Neurologia, Vol. 66. No. 11. pp. 377-386.

Gauthier, S., Albert, M., Fox, N., Goedert, M., Kivipelto, M., MestreFerrandiz, J., \& Middleton, L. T. (2016) Why has therapy develop- 
ment for dementia failed in the last two decades?. Alzheimer's \& Dementia, Vol. 12. No. 1. pp. 60-64.

Giebel, C. M., Sutcliffe, C., \& Challis, D. (2015) Activities of daily living and quality of life across different stages of dementia: a UK study. Aging \& Mental Health, Vol. 19. No. 1. pp. 63-71.

Giorgio, J., Landau, S. M., Jagust, W. J., Tino, P., \& Kourtzi, Z. (2020) Modelling prognostic trajectories of cognitive decline due to Alzheimer's disease. NeuroImage: Clinical, Vol. 26, 102199.

Goetzl, E. J. (2020) Advancing medicine for Alzheimer's disease: A plasma neural exosome platform. The FASEB Journal, Vol. 34 No. 10. pp. 13079-13084.

Grande, G., Qiu, C., \& Fratiglioni, L. (2020) Prevention of dementia in an ageing world: Evidence and biological rationale. Ageing Research Reviews, Vol. 64, 101045.

Grober, E., Hall, C. B., Lipton, R. B., Zonderman, A. B., Resnick, S. M., \& Kawas, C. (2008) Memory impairment, executive dysfunction, and intellectual decline in preclinical Alzheimer's disease. Journal of the International Neuropsychological Society, Vol. 14 No. 2. pp. 266-278

Hampel, H., O’Bryant, S. E., Molinuevo, J. L., Zetterberg, H., Masters, C. L., Lista, S., ... Blennow, K. (2018) Blood-based biomarkers for Alzheimer disease: mapping the road to the clinic. Nature Reviews Neurology, Vol. 14. No. 11. pp. 639-652.

Herrmann, C.S., Rach, S., Neuling, T., Strüber, D. (2013) Transcranial alternating current stimulation: a review of the underlying mechanisms and modulation of cognitive processes. Front. Human Neurosci., Vol. 7. No. 279.

Hodson, R. (2016) Precision medicine. Nature, Vol. 537. No. 7619.

Ienca, M., Vayena, E., \& Blasimme, A. (2018) Big data and dementia: charting the route ahead for research, ethics, and policy. Frontiers in medicine, Vol. 5. No. 13.

Isaacson, R. S., Ganzer, C. A., Hristov, H., Hackett, K., Caesar, E., Cohen, R., ... Krikorian, R. (2018) The clinical practice of risk reduction for Alzheimer's disease: a precision medicine approach Alzheimer's \& Dementia, Vol. 14. No. 12. pp. 1663-1673.

Isaacson, R. S., Hristov, H., Saif, N., Hackett, K., Hendrix, S., Melendez, J., ... Krikorian, R. (2019) Individualized clinical management of patients at risk for Alzheimer's dementia. Alzheimer's \& Dementia, Vol. 15. No. 12. pp. 1588-1602.

Jack, C. R., Albert, M. S., Knopman, D. S., McKhann, G. M., Sperling, R. A., Carrillo, M. C., ... Phelps, C. H. (2011) Introduction to the recommendations from the National Institute on AgingAlzheimer's Association workgroups on diagnostic guidelines for Alzheimer's disease. Alzheimer's and Dementia, Vol. 7. No. 3. pp. 257-262.

Jack, C. R., Bennett, D. A., Blennow, K., Carrillo, M. C., Dunn, B., Haeberlein, S. B., ... Silverberg, N. (2018) NIA-AA Research Framework: Toward a biological definition of Alzheimer's disease. Alzheimer's \& Dementia, Vol. 14. No. 4. pp. 535-562.

Jessen, F., Amariglio, R. E., van Boxtel, M., Breteler, M., Ceccaldi, M., Chételat, G., ... Wagner, M. (2014) A conceptual framework for research on subjective cognitive decline in preclinical Alzheimer's disease. Alzheimer's \& Dementia, Vol. 10. No. 6. pp. 844-852.

Jessen, F., Wiese, B., Bachmann, C., Eifflaender-Gorfer, S., Haller, F., Kölsch, H., ... Bickel, H. (2010) Prediction of dementia by subjective memory impairment effects of severity and temporal association with cognitive impairment. Archives of General Psychiatry, Vol. 67. No. 4. pp. 414-422.

Jonker, C., Geerlings, M. I., \& Schmand, B. (2000) Are memory complaints predictive for dementia? A review of clinical and populationbased studies. International Journal of Geriatric Psychiatry, Vol. 15 No. 11. pp. 983-991.

Kales, H. C., Gitlin, L. N., \& Lyketsos, C. G. (2015) Assessment and management of behavioral and psychological symptoms of dementia. BMJ, 350.

Kivipelto, M., Mangialasche, F., \& Ngandu, T. (2018) Lifestyle interventions to prevent cognitive impairment, dementia and Alzheimer disease. Nature Reviews Neurology, Vol. 14. No. 11. pp. 653-666.
Kluger, A., Gianutsos, J. G., Golomb, J., Ferris, S. H., George, A. E., Franssen, E., \& Reisberg, B. (1997) Patterns of Motor Impairment in Normal Aging, Mild Cognitive Decline, and Early Alzheimer' Disease. The Journals of Gerontology Series B: Psychological Sciences and Social Sciences, Vol. 52B. No. 1. pp. 28-39.

Knopman, D. S., Parisi, J. E., Salviati, A., Floriach-Robert, M., Boeve, B. F., Ivnik, R. J., ... Petersen, R. C. (2003) Neuropathology of Cognitively Normal Elderly. Journal of Neuropathology \& Experimental Neurology, Vol. 62. No. 11. pp. 1087-1095.

Lamb, J. R., Jennings, L. L., Gudmundsdottir, V., Gudnason, V., \& Emilsson, V. (2021) It's in Our Blood: A Glimpse of Personalized Medicine. Trends in Molecular Medicine, Vol. 27. No. 1. pp. 2030.

Licher, S., Ahmad, S., Karamujić-Čomić, H., Voortman, T., Leening, M. J., Ikram, M. A., \& Ikram, M. K. (2019) Genetic predisposition, modifiable-risk-factor profile and long-term dementia risk in the general population. Nature Medicine, Vol. 25. No. 9. pp. $1364-1369$

Livingston, G., Huntley, J., Sommerlad, A., Ames, D., Ballard, C., Banerjee, S., ... Mukadam, N. (2020) Dementia prevention, intervention, and care: 2020 report of the Lancet Commission. The Lancet, Vol. 396. No. 10248. pp. 413-446.

López-de-Eguileta, A., Lage, C., López-García, S., Pozueta, A., García-Martínez, M., Kazimierczak, M., ... Casado, A. (2020) Evaluation of choroidal thickness in prodromal Alzheimer's disease de fined by amyloid PET. Plos one, Vol. 15. No. 9. e0239484.

Marshall, G. A., Rentz, D. M., Frey, M. T., Locascio, J. J., Johnson, K. A., \& Sperling, R. A. (2011) Executive function and instrumental activities of daily living in mild cognitive impairment and Alzheimer's disease. Alzheimer's and Dementia, Vol. 7. No. 3. pp. 300308

McKeith, I., \& Cummings, J. (2005) Behavioural changes and psychological symptoms in dementia disorders. The Lancet Neurology, Vol. 4. No. 11. pp. 735-742.

McKhann, G. M., Knopman, D. S., Chertkow, H., Hyman, B. T., Jack, C. R., Kawas, C. H., ... Phelps, C. H. (2011) The diagnosis of dementia due to Alzheimer's disease: Recommendations from the National Institute on Aging-Alzheimer's Association workgroups on diagnostic guidelines for Alzheimer's disease. Alzheimer's and Dementia, Vol. 7. No. 3. pp. 263-269.

McWhirter, L., Ritchie, C., Stone, J., \& Carson, A. (2020) Functional cognitive disorders: A systematic review. The Lancet Psychiatry, Vol. 7. No. 2. pp. 191-207.

Meszlényi, R. J., Buza, K., \& Vidnyánszky, Z. (2017) Resting state fMRI functional connectivity-based classification using a convolutional neural network architecture. Frontiers in Neuroinformatics, Vol. 11.

Milà-Alomà, M., Suárez-Calvet, M., \& Molinuevo, J. L. (2019) Latest advances in cerebrospinal fluid and blood biomarkers of Alzheimer's disease. Therapeutic Advances in Neurological Disorders, Vol. 12. pp. 1-23.

Mitchell, A. J., Beaumont, H., Ferguson, D., Yadegarfar, M., \& Stubbs, B. (2014) Risk of dementia and mild cognitive impairment in older people with subjective memory complaints: meta-analysis. Acta Psychiatrica Scandinavica, Vol. 130. No. 6. 439-451.

Mitchell, A. J., \& Shiri-Feshki, M. (2009). Rate of progression of mild cognitive impairment to dementia - meta-analysis of 41 robust inception cohort studies. Acta Psychiatrica Scandinavica, Vol. 119. No. 4. pp. 252-265.

Morris, R. G., \& Kopelman, M. D. (1986) The Memory Deficits in Alzheimer-type Dementia: A Review. The Quarterly Journal of Experimental Psychology Section A, Vol. 38. No. 4. pp. 575-602.

Mortamais, M., Ash, J. A., Harrison, J., Kaye, J., Kramer, J., Randolph, C., ... Ritchie, K. (2017) Detecting cognitive changes in preclinical Alzheimer's disease: A review of its feasibility. Alzheimer's \& Dementia, Vol. 13. No. 4. pp. 468-492.

Moussavi, Z., Kimura, K., Kehler, L., de Oliveira Francisco, C., \& Lithgow, B. (2021) A Novel Program to Improve Cognitive Func- 
tion in Individuals With Dementia Using Transcranial Alternating Current Stimulation (tACS) and Tutored Cognitive Exercises. Frontiers in Aging, Vol. 2, 3.

Murdoch, B. E., Chenery, H. J., Wilks, V., \& Boyle, R. S. (1987) Language disorders in dementia of the Alzheimer type. Brain and Language, Vol. 31. No. 1. pp. 122-137.

Nichols, E., Szoeke, C. E., Vollset, S. E., Abbasi, N., Abd-Allah, F., Abdela, J., ... Murray, C. J. (2019) Global, regional, and national burden of Alzheimer's disease and other dementias, 1990-2016: a systematic analysis for the Global Burden of Disease Study 2016 The Lancet Neurology, Vol. 18. No. 1. pp. 88-106.

Nissen, M. J., Corkin, S., Buonanno, F. S., Growdon, J. H., Wray, S. H., \& Bauer, J. (1985) Spatial Vision in Alzheimer's Disease: General Findings and a Case Report. Archives of Neurology, Vol. 42 No. 7. pp. 667-671.

Pache, M. (2003) Colour vision deficiencies in Alzheimer's disease. Age and Ageing, Vol. 32. No. 4. pp. 422-426.

Patterson, C. (2018) World alzheimer report 2018. London, Alzheimer's Disease International

Petersen, R. C., Lopez, O., Armstrong, M. J., Getchius, T. S. D., Ganguli, M., Gloss, D., ... Rae-Grant, A. (2018) Practice guideline update summary: Mild cognitive impairment report of theguideline development, dissemination, and implementation. Neurology, Vol. 90. No. 3. pp. 126-135.

Rahman, M. A., Rahman, M. R., Zaman, T., Uddin, M. S., Islam, R., Abdel-Daim, M. M., \& Rhim, H. (2020) Emerging Potential of Naturally Occurring Autophagy Modulators Against Neurodegeneration. Current Pharmaceutical Design, Vol. 26. No. 7. pp. 772 779 .

Rathore, S., Habes, M., Iftikhar, M. A., Shacklett, A., \& Davatzikos, C. (2017) A review on neuroimaging-based classification studies and associated feature extraction methods for Alzheimer's disease and its prodromal stages. NeuroImage, Vol. 155. pp. 530-548.

Reid, L. M., \& MacLullich, A. M. J. (2006) Subjective Memory Complaints and Cognitive Impairment in Older People. Dementia and Geriatric Cognitive Disorders, Vol. 22. No. 5-6. pp. 471-485.

Roberts, R., \& Knopman, D. S. (2013) Classification and epidemiology of MCI. Clinics in Geriatric Medicine, Vol. 29. No. 4. pp 753-772.

Rutjes, A. W., Denton, D. A., Di Nisio, M., Lee-Yee, C., Abraham, R. P., Al-Assaf, A. S., ... McCleery, J. (2020) Vitamin and mineral supplementation for maintaining cognitive function in cognitively healthy people in mid and late life: a Cochrane Review. BJPsych Advances, Vol. 26. No. 1. p. 2.

Schindler, S. E., \& Bateman, R. J. (2021) Combining blood-based biomarkers to predict risk for Alzheimer's disease dementia. Nature Aging, Vol. 1. No. 1. pp. 26-28.

Serrano-Pozo, A., Das, S., \& Hyman, B. T. (2021). APOE and Alzheimer's disease: Advances in genetics, pathophysiology, and therapeutic approaches. The Lancet Neurology, Vol. 20. No. 1. pp. 68-80.

Shen, X. N., Li, J. Q., Wang, H. F., Li, H. Q., Huang, Y. Y., Yang, Y. X., ... Alzheimer's Disease Neuroimaging Initiative (2020) Plasma amyloid, tau, and neurodegeneration biomarker profiles predict Alzheimer's disease pathology and clinical progression in older adults without dementia. Alzheimer's \& Dementia: Diagnosis, Assessment \& Disease Monitoring, Vol. 12. No. 1. el2104.

Slot, R. E. R., Sikkes, S. A. M., Berkhof, J., Brodaty, H., Buckley, R., Cavedo, E., ... van der Flier, W. M. (2019) Subjective cognitive decline and rates of incident Alzheimer's disease and non-Alzheimer's disease dementia. Alzheimer's \& Dementia, Vol. 15. No. 3. pp. $465-476$.

Snitz, B. E., \& Brickman, A. M. (2020) Do subtle cognitive deficits precede amyloid accumulation?: Cart before the horse. Neurology, Vol. 94. No. 4. pp. 151-152.

Sperling, R. A., Aisen, P. S., Beckett, L. A., Bennett, D. A., Craft, S., Fagan, A. M., ... Phelps, C. H. (2011) Toward defining the preclinical stages of Alzheimer's disease: Recommendations from the National Institute on Aging-Alzheimer's Association workgroups on diagnostic guidelines for Alzheimer's disease. Alzheimer's \& Dementia, Vol. 7. No. 3. pp. 280-292.

Thal, D. R., Rüb, U., Orantes, M., \& Braak, H. (2002) Phases of A $\beta$ deposition in the human brain and its relevance for the development of AD. Neurology, Vol. 58. No. 12. pp. 1791-1800.

Trick, G. L., \& Silverman, S. E. (1991) Visual sensitivity to motion: Age-related changes and deficits in senile dementia of the alzheimer type. Neurology, Vol. 41. No. 9. pp. 1437-1440.

Tzekov, R., \& Mullan, M. (2014) Vision function abnormalities in Alzheimer disease. Survey of Ophthalmology, Vol. 59. No. 4. pp. $414-433$.

Uddin, M. S., Al Mamun, A., Asaduzzaman, M., Hosn, F., Abu Sufian, M., Takeda, S., ... Sujan, M. A. R. (2018) Spectrum of Disease and Prescription Pattern for Outpatients with Neurological Disorders: An Empirical Pilot Study in Bangladesh. Annals of Neurosciences, Vol. 25. No. 1. pp. 25-37.

Uddin, M. S., Al Mamun, A., Takeda, S., Sarwar, M. S., \& Begum, M. M. (2019) Analyzing the chance of developing dementia among geriatric people: a cross-sectional pilot study in Bangladesh. Psychogeriatrics, Vol. 19. No. 2. pp. 87-94.

Vakli, P., Deák-Meszlényi, R. J., Hermann, P., \& Vidnyánszky, Z. (2018) Transfer learning improves resting-state functional connectivity pattern analysis using convolutional neural networks. GigaScience, Vol. 7. No. 12. giyl30.

Vogel, J. W., Young, A. L., Oxtoby, N. P., Smith, R., Ossenkoppele, R., Strandberg, O. T., ... Hansson, O. (2021) Four distinct trajectories of tau deposition identified in Alzheimer's disease. Nature Medicine, Vol. 27. No. 5. pp. 871-881.

Wadley, V. G., Harrell, L. E., \& Marson, D. C. (2003) Self- and Informant Report of Financial Abilities in Patients with Alzheimer's Disease: Reliable and Valid? Journal of the American Geriatrics Society, Vol. 51. No. 11. pp. 1621-1626.

World Health Organization (2019) Risk reduction of cognitive decline and dementia: WHO guidelines. World Health Organization

Xiao, X., Liu, X., \& Jiao, B. (2020) Epigenetics: Recent Advances and Its Role in the Treatment of Alzheimer's Disease. Frontiers in Neurology, Vol. 11. 538301.

Zetterberg, H., \& Blennow, K. (2020) Blood Biomarkers: Democratizing Alzheimer's Diagnostics. Neuron, Vol. 106. No. 6. pp. 881883.

A cikk a Creative Commons Attribution 4.0 International License (https://creativecommons.org/licenses/by/4.0/) feltételei szerint publikált Open Access közlemény, melynek szellemében a cikk bármilyen médiumban szabadon felhasználható, megosztható és újraközölhető, feltéve, hogy az eredeti szerző és a közlés helye, illetve a CC License linkje és az esetlegesen végrehajtott módositások feltüntetésre kerülnek. (SID_1) 